\title{
Foreword: Hong Kong Special Edition
}

\section{前言 : 香港特刊}

This special issue on Hong Kong has been waiting in the wings to be published since the start of 2020 and follows the special issue on COVID-19. It is an important and exciting special issue as Hong Kong art therapists have made great strides over the years and this issue gives us a window into the way they are imagining, thinking, questioning, and debating how to adapt their traditional training to their local contexts. Their commitment to this subject shows a conscientiousness, seriousness, and concern for the people with whom they work and the profession itself. Since the writing of these articles the COVID-19 pandemic has shaken the entire world on multiple levels and no less so Hong Kong. It has highlighted the prominent role of Hong Kong's civil society and the ability of the local communities to engage in spontaneous social mobilization. As a result of their experience during the previous SARS epidemic - the resulting number of deaths as well as the subsequent economic depression - Hong Kong society was quick to respond to this current pandemic. People were disciplined; donning masks, sanitizing their environments, and observing social distancing from very early on, and even before the World Health Organization (WHO) was recommended these as helpful actions.

This quick social mobilization prevented a large-scale community outbreak during the early stages of this pandemic. Indeed, Hong Kong communities have shown tremendous resilience and capacity to adapt. Art therapists in this edition speak of their practice before COVID-9 and of their wish to return to "normal" but also of the advantages gained and lessons learned in adapting their work and lives to taking place online.

We are still in the midst of the pandemic and are only just getting a glimpse of how the pandemic will impact on the world. Just as SARS had a profound impact on Hong Kong society, so inevitably will this pandemic shape the post-COVID era. We do not yet know what this era will look like in Hong Kong or anywhere in the world, but we do know that it is the values of cooperation, cross cultural dialog, and internationalism that characterize this journal. It is our understanding that our differences enrich us and make us more complete and it is in this spirit that this special issue on Hong Kong has been written and compiled. 
这本关于香港的特刊从 2020 年开始就一直在等待时机出版，是继新冠疫情 (COVID-19) 特刊之后的又一本特辑。这是重要而激动人心的一期特刊，因为 香港的艺术治疗师们多年来取得了长足的进展，这一期为我们提供了一个窗口了 解他们正在设想、思考、质疑和辩论如何将接受的传统训练适应本土情境。他们 对这一主题的贡献显示了一种尽责、严谨的态度，以及对工作对象和职业本身的 关切。自這些文章撰写以来，新冠疫情在多个层面撼动了全球，香港也不例外。它 凸显了香港公民社会的显著作用，以及本地社区自发进行社会动员的能力。由于 在SARS 期间的经验——由此造成的死亡人数以及随后的经济萧条——香港社 会对这次全球性流行病的反应非常迅速。人们相当守规则，很早就戴上口罩，对 环境进行消毒，并保持社交距离，甚至早于世卫组织获得各方建议采取这些有 益措施之前。

迅速的社会动员避免了在这次全球性疫情的早期阶段出现大规模的社区爆 发。事实上，香港的社区已表现出极大的复原力和适应能力。本期特刊中的艺术 治疗师们谈到他们在新冠疫情前的实践，希望回归“正常“的愿望，但也谈到 了他们调整工作和生活适应在线方式所获得的益处，以及吸取的经验。

我们仍处在疫情之中，疫情对全球的影响我们瞥见甚微。正如SARS对香港社 会的影响一样，这场全球疫情也将不可避免地塑造后新冠疫情时代。我们还不 知道后疫情时代在香港或世界任何地方会是什么情形，但我们知道，合作，跨文 化对话和国际主义的价值观是本刊的特色。我们明白，彼此的差异会使我们更 丰富，更完整，这本关于香港的特刊就是秉持这种精神而编纂的。

Debra Kalmanowitz, PhD

Co-Editor in Chief CAET 